\title{
Bridging the rural-urban divide for local economic development in Nekemte and its hinterlands, Oromia, Ethiopia
}

\author{
Megerssa Tolessa Walo* \\ Institute for Regional Development, University of Tasmania
}

Submitted November 10, 2015 / Revised January 4, March 6, April 11, and May 4, 2016 /

Accepted May 25, 2016 / Published online September 21, 2016

Citation: Walo, M. T. (2016). Bridging the rural-urban divide for local economic development in

Nekemte and its hinterlands, Oromia, Ethiopia. Journal of Agriculture, Food Systems, and Community

Development, 6(4), 125-143. http://dx.doi.org/10.5304/jafscd.2016.064.012

Copyright (C) 2016 by New Leaf Associates, Inc.

\begin{abstract}
This study explores some of the challenges to strengthening rural-urban linkages for local economic development in the Guto Gidda district of Oromia Region, Ethiopia. Participants were selected from farmers, traders, small-scale processors of maize and niger seed, and government officials using a snowball sampling technique. The primary data gathered related to flows of agricultural produce (maize and niger seed), people, and market information between the actors in agricultural products at Nekemte town and its hinterlands. The information was collected using interviews. Results indicated that despite the

* Megerssa Tolessa Walo, University of Tasmania, Institute for Regional Development, Cradle Coast Campus, Burnie; Tasmania 7320, Australia; Megerssa.Walo@utas.edu.au; megewabi@gmail.com; megerssat@yahoo.com
\end{abstract}

enabling policy of the government to facilitate rural-urban linkages, the linkages in the district remain weak as far as their capacity to improve the overall local economies. Diversification of economic activities is therefore used as a temporary strategy to reduce poverty, but it is a stop-gap venture rather than a strategy that could improve the income of the community at large. In this study, I recommend that investments in rural feeder roads, improved provision of rural microfinance and access to market information, and ensuring affordable agricultural inputs would improve ruralurban linkages and thus lead to stronger local economic development.

\section{Keywords}

Ethiopia; Agricultural Industries; Local Economic Development; Rural Development Policy; RuralUrban Linkages 


\section{Introduction}

The traditional rural and urban dichotomous approach to understanding local economic development (LED) does not always accord with the reality of the contemporary globalized world (United Nations [UN], 2011). Globally, societies are highly interconnected at local, national, and/or international levels (Magel, 2003). At the local level, rural and urban areas are linked together through the flow of people, production, commodities, capital, income, and market information, among other elements, and this makes rural-urban linkages important for LED and poverty reduction (Fritsche et al., 2015). Strong rural-urban linkages, therefore, would encourage new forms of livelihood through diversification and agroprocessing (Steinberg, 2014).

Academics around the world have been debating the pros and cons associated with rural-urban linkages since the 1950s. However, there have been changes in this area over time. In the 1950s policies called for an acceleration of urban industrial growth because urbanization was generally considered to be associated with modernization (Sani \& Far, 2015). By the 1970s, development approaches shifted to integrating infrastructure in rural areas to achieve rural developmental goals; this also was correlated with a reduction of comparative disadvantages for competition and utilization of rural resources (Nemes, 2005). In the 1980s it was recognized that these dichotomous development approaches had failed to bring the intended development outcomes, and therefore, rural-urban linkages have emerged as a development approach in regional planning (UN, 2011). A study by Tegegne (2001) indicated that an attempt to bring about rural development has been made by focusing on structural sectoral problems in Ethiopia; however, this has failed to achieve the desired changes. The rural-urban linkages approach to development focuses on the mutual development of both urban and rural areas for a strong local economy. It is assumed that both the areas are interdependent through the flow of resources and other linkages. Urban areas provide markets for agricultural and rural commodities, while rural areas provide agricultural surpluses to the urban area (Akkoyunlu, 2013).
In Ethiopia, the government views rural-urban linkages as a policy priority for rapid economic development, and it has been introducing successive development policies that encourage ruralurban linkages since 2002/03 (MoFED, 2007). These policy frameworks include the Sustainable Development and Poverty Reduction Programme (SDPRP) and the Plan for Accelerated and Sustainable Development to End Poverty (PASDEP), among others. PASDEP was considered to be the most comprehensive policy framework and was implemented between 2005/06 and 2009/10. The First Growth and Transformation Plan (GTP), $2019 / 10$ to $2014 / 15$, closed recently, and the second GTP is to be implemented from 2016 to 2020 (Federal Democratic Republic of Ethiopia [FDRE], 2015).

The initiatives under each framework were built on the results from those of the previous initiatives. The initiation of PASDEP pointed out the need to strengthen rural-urban linkages to maximize growth and reduce poverty by taking full advantage of the synergies provided by market integration, labor mobility, and access to incomeearning opportunities between urban and rural areas (MoFED, 2005). It also underlined the importance of improving infrastructure (rural access roads, telecommunication, and rural electrification), and developing small-scale credit markets as key instruments to facilitate rural-urban linkages. PASDEP linked rural transformation with electrification since it made clear that electricity transforms rural economies not only by providing the basis for businesses and agro-processing at regional and/or zonal towns but also as an input into agriculture for irrigation pumping, commercial agricultural production, and processing. The rural transformation intended to prevent migration to urban areas and also to use the byproducts from agro-processing industries to be channeled back to the field. It was also expected to enhance the modernization of agricultural production, which could attract investors interested in agricultural production and establish ancillary industries in the regions (FDRE, 2010). In PASDEP's urban development strategy, rural-urban linkages were considered to be one of the pillars whereby emphasis was given to the development of small towns as 
major entry points of resources (MoFED, 2005).

According to the government's evaluation, PASDEP achieved most of its desired goals. The report also indicates that gross domestic product (GDP) increased from $7 \%$ in $2005 / 06$ to $11 \%$ in $2009 / 10$, with the share of agriculture and industry being $8.4 \%$ and $10 \%$, respectively. In terms of infrastructure, the numbers of kilometers of allweather roads increased from $36,400 \mathrm{~km}(22,618$ miles) in $2004 / 05$ to $48,800 \mathrm{~km}$ (30,323 miles) in 2009/10; these figures exclude those in the district or rural areas (FDRE, 2010; Nuru, 2015). Mobile telecommunication network capacity was increased from 0.5 million users to 25 million users.

PASDEP was also used to generate $2000 \mathrm{MW}$ (61\% of its objective) of electricity at the end of 2009/10 (FDRE, 2010).

However, scholars question the credibility of the FDRE report as it lacks independent verification (Teshome, 2006). Telecommunications, utilities, civil aviation, and financial services remain solely or largely under government control, limiting the services they provide as there is no other alternative provider. There have been reports that the state-owned telecom provider is failing even to provide basic services, and this is negatively affecting rural-urban linkages and development of the localities and beyond. The government also influences the strategic direction of economic development through party-linked holding companies, or "endowment companies," as they are known in Ethiopia (Jalata, 2015).This has a negative impact on rural-urban linkages as well as the economy of the country at large. Others studies have indicated that the lack of specific emphasis by the PASDEP on rural-urban linkages as specific development agendas in the macro policy framework are partially responsible for perpetuating sectoral development and policy implementation (Dorosh et al., 2011). This lack of focus reflects a continued emphasis on traditional development debates and policies focusing on economic sectors (agriculture and industry), rather than on integrating geographic areas (rural and urban), along with an implicit assumption that agriculture can be equated with rural areas and industry with urban areas (Dorosh et al., 2011). Thus, it becomes necessary to examine empirically whether these government policies have achieved their aims in developing stronger linkages, and if not, why. This study aims to identify some of the underlying causes contributing to weak rural-urban linkages. The importance of the study rests in the fact that LED-related studies are under researched; this is particularly true in the study area.

\section{Objectives of the Study}

The paper has two specific objectives: (a) to identify the major obstacles to maximizing value from rural-urban linkages and LED; and (b) to suggest possible ways to foster rural-urban linkages to help strengthen LED in the study area.

\section{Rural-urban Linkages in Local Economies}

Urban and rural areas have been defined based on various criteria, including population size and density, economic activity, administrative functions, and infrastructural development (McGranahan \& Satterthwaite, 2014). Administration and demography are the two major criteria for a successful rural and urban linkage (Tacoli et al., 2015). In Ethiopia, the Central Statistical Agency (CSA) has defined urban areas as localities with 2,000 or more households since the implementation of the CSA's first census covering the entire population in 1984. Urban areas include administrative capitals of different regions, zones, and districts, as well as localities with at least 1,000 people who are primarily engaged in non-agricultural activities, and/or areas where the administrative official declares the locality to be urban. In addition to population size, the government uses three other criteria to classify an area as an urban center: the strength and role to lead as a center of development for the surrounding environs; political roles; and historical and cultural roles (Gete, Trutmann, \& Aster, 2007).

When formalized and promoted by government policies, rural-urban linkages have the potential to promote strong LED by contributing to the well-being and livelihoods of the residents and providing an exit out of poverty (Gete, Trutmann, $\&$ Aster, 2007). Sustainable rural growth and urban growth are positively correlated, because stable urban service sectors may provide more jobs by absorbing migrant laborers from the rural areas and supplying (semi)processed products to the migrant 
laborers, which in turn generates a significant proportion of urban incomes (Adugna \& Hailemariam, 2011). Strong rural-urban linkages enhance sustainable LED as the linkages channel resources from producers to consumers, creating economic benefits for the residents (Akkoyunlu, 2013). These linkages have also the potential to stimulate diversification of economic activities in rural areas, particularly when they are in geographic proximity (Dorosh et al., 2011; Mushir \& Meaza, 2013). Livelihood diversification assists capital and asset accumulation (Dorward et al., 2009), whereby farm households with farm assets have access to urban networks in which they can re-invest profits from urban-based activities in agricultural production, and vice versa. This diversification, therefore, is an important element of the "virtuous circle" of ruralurban economic development, where the role of infrastructure linking producers to domestic and external market is significant. The "virtuous circle" model asserts that the higher the income from the production of agricultural goods for nonlocal markets, the more the demand for consumer goods among rural households, leading to diversification (Tacoli, 2004).

Rural-urban linkages are influenced by factors including institutional (market and financial), infrastructure, development policy, and accessibility of farmland (Akkoyunlu, 2013; Sietchiping, Kago, Zhang, Augustinus, \& Tuts, 2014, 2015). Market institutions influence the income of households, especially when some actors, such as traders, ${ }^{1}$ are able to enforce market-controlling mechanisms favoring access for specific groups at the expense of others. The capacity of both urban and rural areas to satisfy the production-consumption demands of their people helps to determine the strength of the linkages. Physical infrastructure (such as roads) and information communication technology play central roles in bridging the ruralurban divide by facilitating linkages between the agricultural and non-agriculture sectors of the economy (Sietchiping et al., 2014). Particularly in developing countries, distance to markets and lack

\footnotetext{
${ }^{1}$ Traders in this study include local retailers and collectors (big traders); local collectors and intermediaries (small traders); and external retailers (bigger traders).
}

of roads jeopardize the livelihoods of the rural poor. These issues result in the rural poor have difficulty gaining access not only to competitive markets for their produce, but also to inputs, assets, technology, consumer goods, credit, and labor (Khor, 2006). Development policy can influence rural-urban linkages by creating favorable conditions for strengthening the linkages by providing for infrastructure and the developing small urban centers and their surroundings (Akkoyunlu, 2013). In Ethiopia, small and intermediately sized urban centers serve as markets and service centers for local agricultural producers and also as administrative centers (Dorosh \& Thurlow, 2013; Fitsum, 2013). They also occupy a space in the middle of the rural-urban continuum where both urban and rural characteristics prevail (Satterthwaite \& Tacoli, 2003).

\section{Description of the Study Area}

This study was conducted in Nekemte town and its hinterlands in the Guto Gidda district of Ethiopia. Guto Gidda district is located in East Wollega Zone of Oromia region, situated between $08^{\circ} 59^{\prime}$ and $09^{\circ} 06^{\prime} \mathrm{N}$ latitude and $37^{\circ} 51^{\prime}$ and $37^{\circ} 09^{\prime} \mathrm{E}$ longitude. There are 29 farmers' associations (FAs) in the district. I selected Uke (with 754 household members) and Negassa (with 655 household members) FAs because agricultural products used for this study are best grown in these two areas. Maize (Zea mays) is dominant in Uke FA, and niger seed (Guizotia abyssinica) is grown well in Negassa FA (ORS, 2014). The district is bounded by Gidda Ayana and Limu districts in the north, Leka Dulecha district in the south, Wayu Tuka and Sibu Sire districts in the east, and Digga and Sasigga districts in the west (see Map 1).

Nekemte and Asela towns in the Oromia region were included in the country's sectoral LED in 2009 (FDRE \& U.N. Development Programme [UNDP], 2012). Nekemte was chosen for this study due to the dominance of maize and niger seed production in the surrounding areas, which was used to analyze the rural-urban linkages and LED.

Guto Gidda district is endowed with a wide range of agro-ecological zones, ranging from warm weather in the low-altitude areas to cool weather in 
Map 1. Location Map of Guto Gidda District

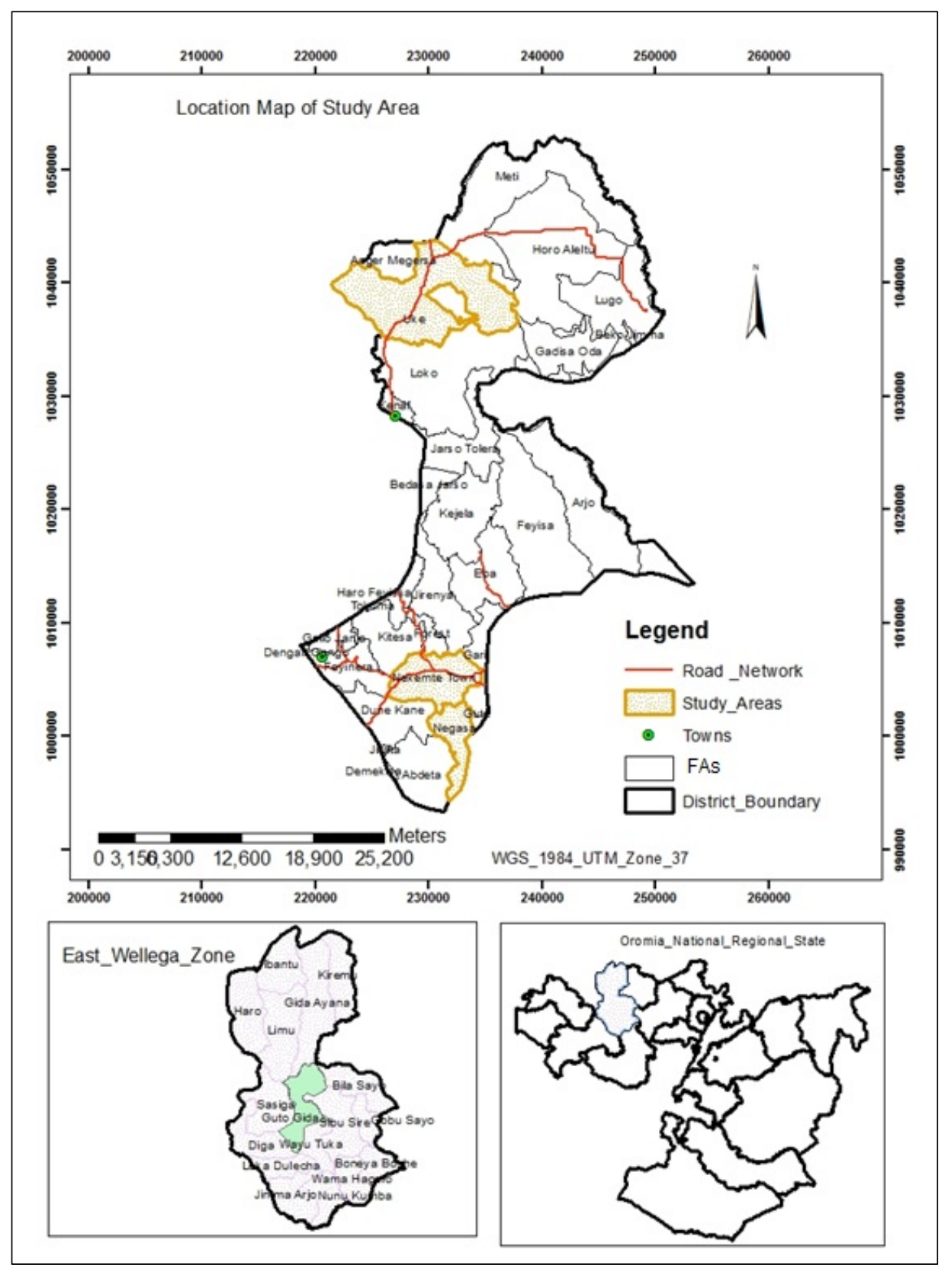

annual rainfall between and $580 \mathrm{~mm}$ and 2,200 $\mathrm{mm}(23$ inches and 87 inches) (GGFEDO, 2013). Most residents are agrarian and reside in the rural areas. Its total population was 105,332 heads in 2013 (NRGO, 2014). There are also a few small market centers, including Bandira in the Negassa FA, where small-scale traders collect maize and niger seed from the farmers and trade the commodities in the nearby secondary markets (ORS, 2014). Nekemte town is the capital of Guto Gidda district and also of East Wollega Zone. It is located at a latitude of $9^{\circ} 46^{\prime} \mathrm{N}$ and longitude of $36^{\circ} 31^{\prime} \mathrm{E}$. According to the FDRE Central Statistical Agency (2013), the population of Nekemte town was 115,741 heads.

\section{Socio-economic Profile of the Respondents}

The research participants were from both urban and rural areas and represented farm households, traders,

higher altitude areas, resulting in a favorable environment for the production of different types and varieties of crops, including cereals (maize, sorghum, teff), oil seeds (niger seed and sesame), and pulses (beans). Information obtained from the Finance and Economic Development Office of Guto Gidda indicates that the district enjoys tropical and subtropical climates, with an average annual temperature between $16^{\circ} \mathrm{C}$ and $31^{\circ} \mathrm{C}$, and small-scale processors of maize and niger seed, and local government officials. Data from the field indicates that the majority of the farm households were small-scale farmers $(70 \%)$ with subsistencelevel production. Female respondents (including female-headed households) account for $37 \%$ of the rural household research participants. Data from Nekemte city administration show that the major sources of income for urban households in 2012 
include salaries, self-employment, rent income, remittance, wages from daily labor jobs, and agriculture (NCD, 2012). Nearly half its households face a shortage of income to support their livelihoods, which is aggravated by low-productivity self-employment (NCD, 2012). Uke and Lugo towns, located to the north and northeast of Nekemte town, respectively, are defined in this study as small urban centers, as they are centers of agricultural products exchange for the local people. In terms of counting, however, the Central Statistical Agency included the population in the two areas under rural (FDRE, CSA, 2013). Uke ${ }^{2}$ district town is the center of grain (including maize and niger seed) collection for traders coming from Nekemte town.

\section{Study Methodology}

\section{Sampling Methods}

This study applied the principle of data saturation and attainment of quality (Saunders, Lewis, \& Thornhill, 2009) that a small sample size can achieve. A study by Curry, Nembhard, and Bradley (2009) recommends a sample size between 20 and 30 research participants, while Kvale (1996) suggests fewer (between 5 and 25 respondents) for an interview study, especially when heterogeneity and saturation are the driving forces of the research. This study provides a basis to understand the roles played by various LED actors to triangulate and generate a detailed and rich data.

The respondents were selected using the snowball sampling technique. I first approached the district agriculture office (DAO), where I described the study objectives. Study sites were selected after reaching consensus with local authorities. Uke and FAs were purposively selected because they are associated with the cultivation of maize and niger seed. The respondents were also purposively identified based upon farm scale, gender, and business scale, followed by random selection. In the second stage, development agents (DAs) of the selected sites were contacted as key informants; they were also asked to identify potential respondents because they are local experts. Care was taken

${ }^{2}$ Uke is the name of the town and also of the district. to include research participants with different backgrounds and attributes, such as farm scale (large, medium, and small scales ${ }^{3}$ ), gender, and education. Accordingly, 30 agrarian households ${ }^{4}$ (nineteen males and eleven females), nine traders (five males and four females), five millers (four males and one female), five edible oil processors (all males), and two agricultural extension workers (one from each sex) were interviewed. The names of all interviewees were coded for the purpose of gathering and presenting the data, which commenced with personal interviews (PIs), followed by economic activities and locations of the respondents.

\section{Data Collection}

A qualitative research design was used in this study to collect both primary and secondary data and to investigate the flows of commodities (maize and niger seed), people, finance, and market information between Nekemte town and its hinterlands in Guto Gidda district. These two crops were selected because maize plays a significant role in the food security of the country in general and of the study area in particular. It is the second most widely cultivated cereal crop after teff (Eragrostis tef) (Dorosh \& Rashid, 2013), and is the most important staple food product in terms of calorie intake, especially in rural Ethiopia (Abate et al., 2015). Niger seed is an economically important edible oil seed crop constituting about $50 \%$ of the oilseed production in the country (Syume \& Chandravanshi, 2015). Apart from its domestic importance as a source of edible oil, it is exported to different countries and generates much-needed foreign currency for the country (Allaro, 2011).

In-depth qualitative semistructured interviews were used for the data collection because of their ability to gather information from nonliterate participants (Engelmann \& Isiaho, 2005). The questions were different for different participants. The study

\footnotetext{
${ }^{3}$ According to the DAO classification, on average, large-scale, medium-scale and small-scale farmers are those who own 8 ha (19.8 acres), 3 ha (7.4 acres), and less than 0.5 ha (1.2 acres), respectively. ${ }^{4}$ Four of the females and all of the males were household heads.
} 
was conducted between November 1, 2013, and June 1, 2014. Most of the questions were related to the significance of the flows of people, production, and information between Nekemte town and its hinterlands to the peoples' livelihoods. The questions were also aimed at identifying the major barriers (such as those related to credit, genderbased opportunities or constraints, and infrastructure) to the rural-urban linkages and LED. Narrative explanations were tape-recorded and transcribed. These audiorecordings were complemented by field notes, which included observations of verbal and nonverbal behaviors as they happened, and immediate personal reflections about the interview.

\section{Data Analysis Methods}

Data from the interviews and secondary sources were analyzed using qualitative methods. All the recorded conversations were transcribed verbatim, and themes were identified as to the major factors affecting production, processing, and marketing of maize and niger seed. Principles of case-study analysis, including addressing all the evidence and examining major rival interpretations, focusing on the most significant aspects of the case study, and employing the researcher's prior knowledge, as suggested by Yin (2008), were used to further the analysis. To interpret the results, interview data from various categories of research participants (including farmers, traders, and processors) and publicly available data in the district on agroprocessing and marketing of maize and niger seed were assessed and compared with results of similar studies conducted in Ethiopia and in other developing countries.

\section{Results and Discussions}

\section{Findings}

The supply of maize and niger seed available from rural areas is one of the determining factors for the linkages they have with urban areas. Production of grains is a function of farmers' access to farmland, proper and timely access to and procurement of agricultural inputs, well developed and efficient extension services, and infrastructure, among other factors. Low productivity from agricultural land is correlated with land degradation, which is attributable to poor soil management as well as deforestation and inadequate access to inputs that can rejuvenate the nutrients lost through cropping (Jolejole-Foreman, Baylis, \& Lipper, 2012). As in much of the developing world, Ethiopia in general, and the study area in particular, rural-urban linkages are often fraught with mistrust and multiple inefficiencies of the various actors associated with the production and value chain (Dalipagic \& Elepu, 2014; Makosa, 2015). Moreover, there is a lack of support policies to bridge the mistrust as well as a lack of guidance and coordination. The cumulative effects of these problems have weakened the LED.

\section{The rural element of LED in Guto Gidda district}

Constraints: Subsistence production in the rural areas is a threat to the prospects of rural-urban linkages and development of the district. However, the ad hoc linkages between the two can be a potential for the same. Insufficient cropland holdings constrain production. In Guto Gidda district, over $66 \%$ of the respondents were smallscale farmers (owning less than 1.5 hectares or 3.7 acres of farmland). These respondents were not able to meet their families' demands for food as they are unable to produce enough crops. The agriculture is rain-fed and the land does not produce enough food to meet even their basic requirements (Regassa, Givey, \& Castillo, 2010). Data obtained from the DAO provide further evidence that many rural poor are unable to meet their basic needs and are chronically food insecure. Some farmers do not have farmland apart from a small parcel in their back yards. For instance, a farmer from Uke FA, who has half a hectare (1.24 acres) of farmland, and is a father of four, states the seriousness of the problem leading to his "diversification" as follows:

\section{Because I cannot feed my family given my small and low productive farmland, I do many things that help me get money, including daily labor works on the farmland of the investors. ${ }^{5}$ I cannot even afford to}

\footnotetext{
${ }^{5}$ Investors in this case are those who lease extensive farmland from the government to produce mainly maize. They are
} 
buy food when we finish what we harvested, let alone

buy inputs for the next production. (PI, male

collector $^{6}$ in Uke FA)

Access to credit is a major issue that prevents farmers from overcoming limited land size or developing other businesses. The financial shortages the small- and medium-scale farmers face compromise their production potential for the urban market because they are unable to buy oxen and agricultural inputs. Although they could rent land under sharecropping arrangements, it is impossible for them to cultivate it effectively. A widowed small-scale farmer from Negassa FA explained her problem of production as follows:

Apart from the shortage of land, I have a serious problem of finance. If it were not from this financial shortage, I would have done small business and get more income to buy grains for food and agricultural inputs. (PI, female small-scale farmer in Negassa FA)

There are some financial institutions operating in the district, including Commercial Bank of Ethiopia, Oromiya Credit and Saving Share Company (OCSSCO), and Wasasa Microfinance Share Company, which provide financial services. The Farmers' Cooperative Union of East Wollega zone, Gibe Didessa Farmers' Cooperative Union (GDFCU), sometimes provides loans for its members. Both OCSSCO and Wasasa have a mission of poverty alleviation through providing financial services to the poor farmers and others engaged in small-scale production and services. Nonetheless, the majority of rural people in Ethiopia prefer using indigenous financial institutions to formal financial institutions. A study revealed that in 2009 only $1 \%$ of rural households maintained bank accounts (Tenaw \& Islam, 2009). In any case, the formal institutions need to ensure that applicants have no overdue credit and that they have the potential to repay the money on time. Even if they provide approve a loan, they prefer to provide

usually businessmen who live within Oromia region or beyond. ${ }^{6} \mathrm{~A}$ collector is a wholesaler who buys from small producers and sells to larger ones. goods in kind rather than cash as they are skeptical of the likelihood of repayment. If the loan recipients spend the cash on social matters such as for recreational purposes, it does not go toward helping the farmers improve their businesses.

Indigenous financial institutions such as qunqubee also provide finance. Qunqubee ${ }^{7}$ is a rotating saving and credit association whereby members meet regularly (most often monthly) to collect contributions of an equal amount from every member. It is an informal way of saving with no interest paid on the amount collected. It is a type of recurring deposit outside any formal financial institution where members collect a set amount from each other and the collected amount is paid to one of the members on the basis of a lottery. The money collected through these institutions can be used for business or any other household expense (Tenaw \& Islam, 2009). However, in rural areas, the contribution members can make is very small, and thus payouts are of limited value when setting up a start-up business. Those who participate have "regular income," for example from selling their agricultural products such as butter and grains, or they run a small business.

Other factors hampering effective trading include poor market information and lack of coordination and trust between value chain actors (Trienekens, 2011). Market information is crucial for a healthy flow of commodities between urban and rural areas. It is an important means of developing mutual and trust-based trade relationships between farmers and traders or buyers. In Guto Gidda district, however, information flows between traders and farmers are poor. The information that does flow between parties is often not used because the sources of the information determine its credibility. Farmers thus do not get reliable market information. They rely most heavily on information they get from relatives, friends (both in the villages and town), fellow farmers, and above all by going to the market center in person. This affects their maize and niger seed sales and affects the farmer-trader relationship. An interview with a farm household in Uke FA states the

\footnotetext{
${ }^{7}$ Qunqubee is an Oromo term referring to an indigenous financial institution used for credit and saving.
} 
Figure 1. The "Survival Strategy" of Rural-urban Linkages and Local Economic Development (LED) in Guto Gidda District

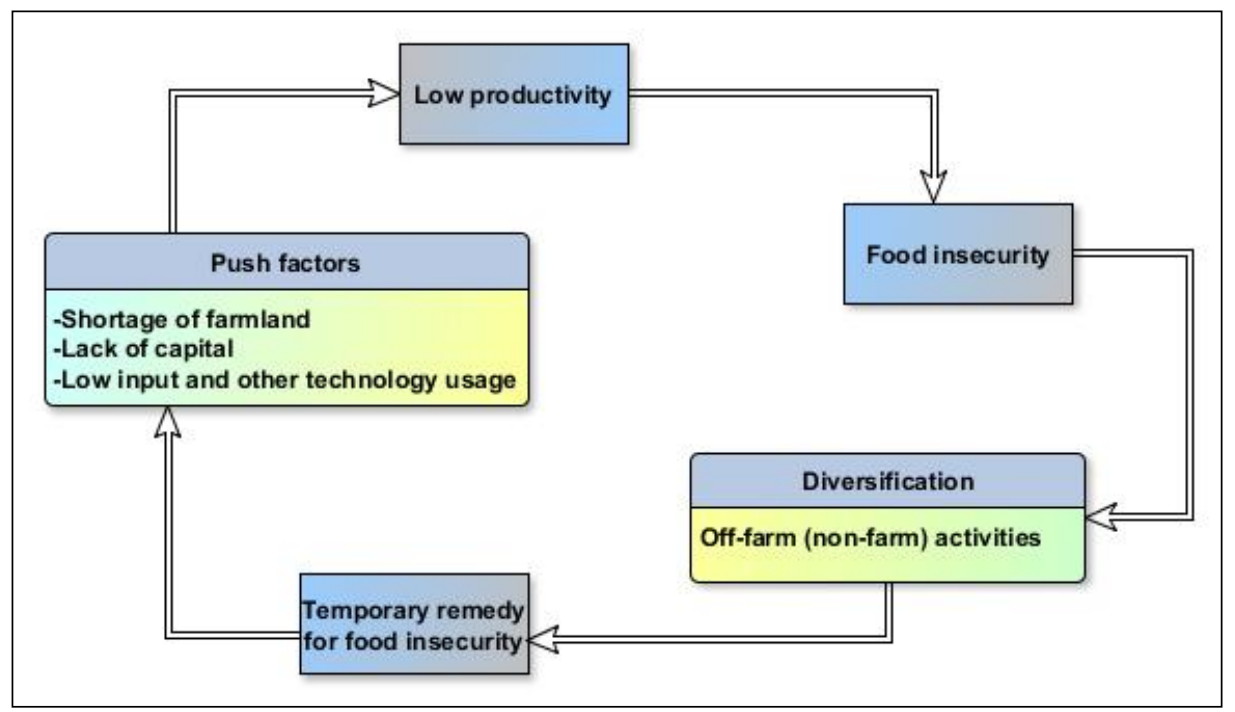

district town at least twice a week for trading purposes. The lack of feeder roads linking villages to the main road in the area, however, is one of the bottlenecks to LED (Gebre-Selassie \& Bekele, 2012). Recently, the provision of mobile telecommunication networks in rural areas has improved information flow. Nonetheless, the majority of farm households cannot afford to use the technology. Processing is also challenged by

situation as follows:

\section{Lack of organized market relationships and reliable information flow between the farmers and traders affects our livelihood. Everyone does his/ her business independently with no coordination. If we could have such relationships, we could form an agreement on supplies which would help us to provide sufficient and quality grains to consumers. (PI, male farmer in Uke FA)}

This interviewee underlines the lack of coordination in the grain value chain. The absence of coordination negatively affects the quality and quantity of products flowing between urban and rural areas. Farmers rarely trust traders or collectors because they believe that traders usually give incorrect market information in order to increase their profit margins. Some farmers mix bad-quality grain (including rotten) with good grain when they sell to the traders, which affects the latter's profit.

The availability and affordability of infrastructure (including road, information communication facilities, and power) are additional determining factors for the grain value chain between urban and rural areas (Von Braun, 2007). In the district, an all-weather gravel road linking Nekemte town to Bure town (in Amhara region) passes through Uke market town. Traders and collectors visit Uke power outages; as one processor puts it, "power get on and off frequently. $" 18$ Even though all the processors (millers and edible oil processors) need electric power for their processing, grain millers sometimes use mills supplied with generators. This is especially true in remote villages where there is no electric power supply. Oil processors, however, are dependent on electric supply to operate their expellers. In the absence of a regular and dependable power source, the processors cannot operate their machinery. Thus in spite of a high demand of cooking oil the supply is limited due to infrastructure-related constraints.

Livelihood diversification: Households in both urban and rural areas in the district typically diversify their activities as a means of livelihood support, an indication that this is a survival strategy (Figure 1). In Uke district town, there are smallscale businesses involving people from the center and the surrounding villages. Urban households also engage in farm activities in their backyards and/or in the rural areas where they get the land from their families, relatives, or friends, or rent from farmers.

A number of farmers seek off-farm income generation as a livelihood strategy. Out of the 30

${ }^{8}$ PI with an edible oil processor in Nekemte town, 2013/14. 
total farm households interviewed in the district, $21(70 \%)$ reported they are engaged in either offfarm or nonfarm activities besides their regular farming business (Table 1). Farmers in Uke FA mostly cultivate maize, while those in Negassa produce both maize and niger seed, depending on the micro-agro ecology of the areas. Similarly, out of nine traders interviewed in the Uke district town, four $(44 \%)$ responded that they are also engaged in farming activities in addition to trading part-time in agricultural products. Most of the residents in Uke district town are involved in various activities, such as having a small business, being a street vendor, have small eateries (bars and restaurants), besides milling and retail trading.

\section{Table 1. Household Economic Activity in Guto Gidda District}

\begin{tabular}{lc}
\hline Occupation & $\%$ \\
\hline Farming and daily wage labor & 40 \\
Farming only & 30 \\
Farming and sale of local food and drinks & 13.33 \\
Farming and local trade & 3.33 \\
Farming and local government employee & 3.33 \\
Farming and Others & 10 \\
\hline Total & $99.99 \%$ \\
\hline
\end{tabular}

Source: Computed from field data (2014).

Wage labor: The study indicates that most of the respondents who have off-farm or nonfarm activities served as daily or wage labor, followed by those associated with small businesses, mainly selling locally made food items and drinks, and then by those associated with construction activities. It has also been reported in this study that adults and young (school-age) males who are engaged in daily labor commute long distances to seek work. Many adults also encourage their children to contribute to these activities. The children above 18 years old do odd jobs to earn some money on days they are out of school. A small-scale farmer in Negassa FA explains:

My children do daily wage jobs after school on the farmland of the investors to earn some money. They have managed to buy their clothes, shoes, and school materials and I don't worry about them. During their holidays, they go to Nekemte town to do casual jobs in construction industries to get money. (PI, male small-scale farmer in Negassa FA)

The frequency of travel by interviewees depends on the nature of jobs available and also on the proximity of the villages to the town itself. Residents of rural areas immediately bounding the towns commute on a daily basis, while others further away (30 km or 19 miles or more) do not. The latter visit the towns during market days. The proximity of Negassa FA to Nekemte town, in particular, allows farmers to commute frequently (even daily) and be employed as daily wage labors or in vending agricultural products in the street. However, this commute is more common during peak market days of Nekemte town, which occur twice a week.

The seasonality of wage labor opportunities in these towns limits the income of wage laborers. During peak harvest times (mainly in Uke district), wage laborers move into the district town from surrounding rural areas (and also from Nekemte town) to harvest maize on investors' farmland, located close to Uke district town. These wage laborers are migrants who are most often landless farmhands and who therefore depend solely on such activities. During this time, the laborers reside in the farm area or in the nearby Uke district town until the harvest is over. After this season, the wage labor opportunities are few, and thus their livelihood options are limited. Construction activities in Nekemte town are also seasonal. The aggregate of these limitations results in weak spatial and sectoral linkages between the town and its hinterlands, which leads to poor LED.

Small businesses: Most of the female respondents were engaged in making food and local drinks such as farsoo and bookaa (locally made beer) for local markets. They also own coffee and tea shops. Further, they do petty trading and street vending at Nekemte and Uke markets, where they sell products such as vegetables and fruits along the streets. Of the female street vendors, the majority are household heads, who do this work because they are responsible for the welfare of their family. In 
Bandira market center, situated in the Negassa FA, the farmer-traders (working as commission agents) collect agricultural products such as cereal, oilseeds, and animal products (including butter) from their fellow farmers and sell at Nekemte market. They usually get initial capital to run the business from traders in Nekemte town, who collect the products from them. The income they get from such diversification helps them feed their families, which the DA called a "coping mechanism." One such farmer explains:

\section{Farmers try to cope up with livelihood difficulties by diversifying and mixing activities. Shortage of land, poor land productivity and low purchasing power to buy modern agricultural inputs all contribute to the subsistence production in this area. They supplement their small-scale farm by other allied farming activities viz: apiary, rearing poultry, and grains trading among others. (PI, female DA in Negassa FA)}

Most of the respondents indicate that they diversify their activities because they are food insecure, particularly during summer seasons (June, July, and August) when there are limited nonfarm activities in both Nekemte and Uke district towns. The businesses of the small traders are also not large enough to support their livelihoods. An interview with a grain collector in Uke FA illuminates that he has some doubts about the sustainability of his business, and that is why he and his wife run another business to support their livelihood. He is a buyer based in Uke district town, but is also a farmer. He stations his scales in front of his house, where he collects maize from farmers and sells to other traders and collectors at the end of the day. At the same time, he supervises a small business which his wife runs during the two market days of the district town (Tuesdays and Fridays). He explains the condition of his business as follows:

\section{I do not depend only on grain trading. I have farm fields and other small business in this town to support my livelihood in case my trading fails. (PI, male collector in Uke FA)}

His wife makes booka and sells it at her house.
This business is a shared family or household business, because while the wife is in charge of mostly the indoor business, the husband is responsible for the outdoor business. Though the husband consults his wife on how, where, and when to spend the money obtained from the indoor and outdoor businesses in his family, the final decision is usually made by the husband as per the communities' social norm (Geleta, Birhanu, Kaufman, \& Temesgen, 2015).

\section{The urban element of LED in Guto Gidda district}

The connection the value chain actors, such as traders, small-scale manufacturers, and government workers, have with rural areas has direct implications for the nature and forms of rural-urban linkages in specific localities. This, in turn, influences LED. Nekemte town and other district towns and marketplaces are the sources of semiprocessed products, agricultural inputs, and employment opportunities. They are also a place where the rural products under study are exchanged and should be able to stimulate LED.

Maize and niger seed value chain: Despite the constraints negatively affecting the flows of resources between urban and rural areas, data gathered in this study indicate that a value chain does exist between Nekemte and its hinterlands in Guto Gidda district. The major actors include farmers, traders, small-scale manufacturers (processors), the farmers' cooperative union (FCU), and the DAO. The DAO provides agricultural inputs such as fertilizers, seeds, and technical assistance to the farmers through the FCU and DAs. The FCU provides the inputs to those farmers who can afford to buy them. The DAs help the farmers with technical advice in production processes. The farmers produce maize and niger seed grains for consumption locally and beyond. Traders and intermediaries buy grains from farmers and sell to consumers and processors. They also buy niger seed oil from processors and transport and distribute it to consumers and other collectors within Guto Gidda district and surrounding districts. Processors produce edible oil from niger seed. Millers grind maize to produce maize flour for consumption (Figure 2). Small-scale manufacturers also buy maize and niger seed 
Figure 2. Maize and Niger Seed Value Chain Diagram in Guto Gidda District

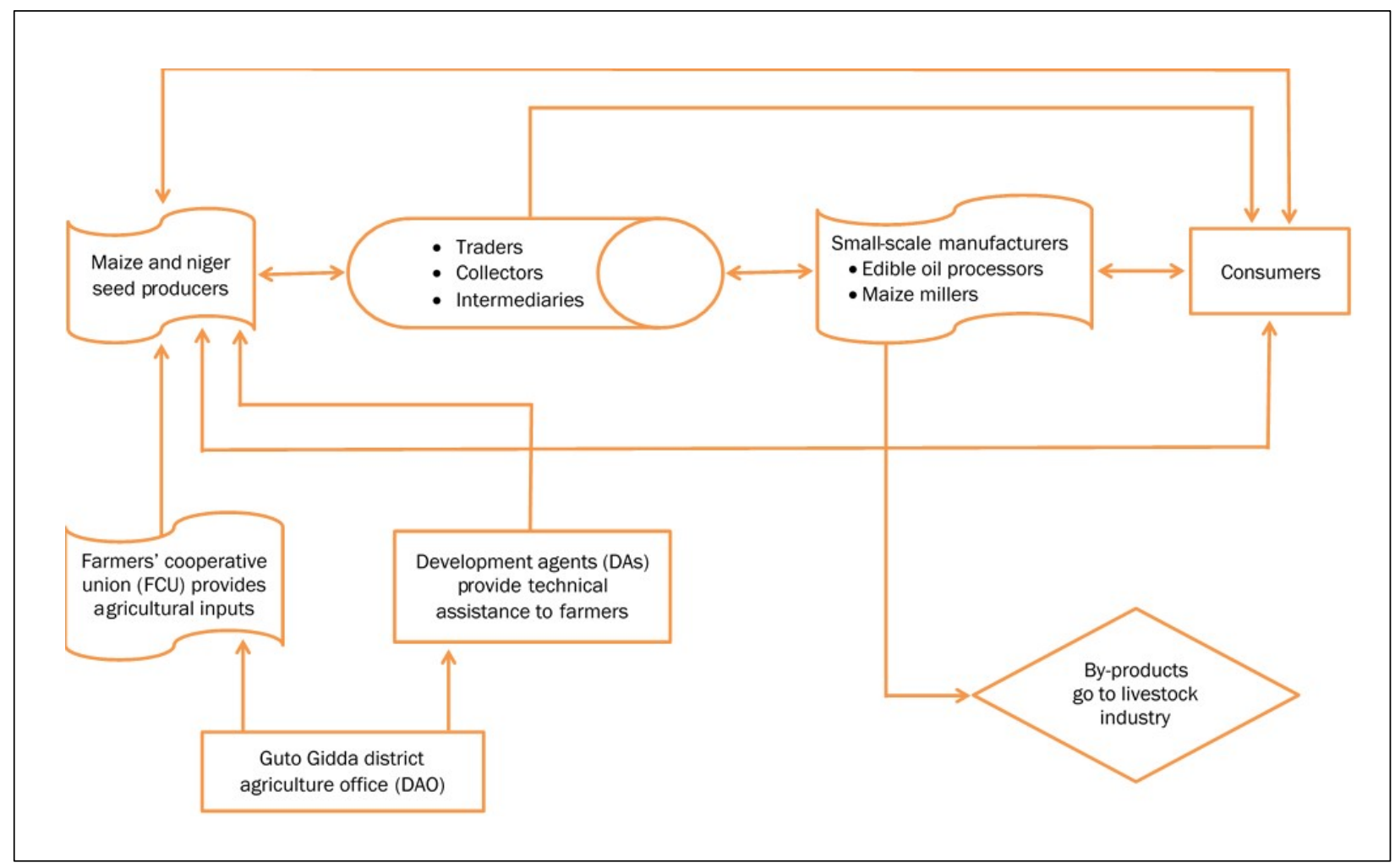

directly from producers. Finally, the byproducts from this agro-processing go to the livestock industry.

Small urban traders: Small traders are one of the key value chain actors. All the traders interviewed in Uke district town have a business relationship with traders in Nekemte town. They usually collect grains (maize and niger seed) from farmers at the farm gate or Uke market center and sell them on to bigger traders or collectors in Nekemte town. The majority of the local collectors and buyers also borrow money from Nekemte town traders to whom they then sell the grains. This indicates a relatively strong mutual trade relationship between the two. Even though this trade relationship helps their business in one way, the small collectors are required to sell back to the collectors and traders who provided the initial money to buy the grains. This limits their freedom to look for better prices for their collected grains. The bigger traders determine the price, which gives them an advantage over the small traders.
The capacity of an urban center to provide the necessary resources for the rural areas in its vicinity dictates the linkages between the two. Nekemte town and other district towns such as Uke have a poor capacity to stimulate effective LED because of their inability to provide the necessary services to the rural hinterlands (and thus to their residents). The negative impact from the shortage or lack of capital on LED in urban areas is significant. The urban poor and small-scale traders have problems similar to their rural counterparts when seeking to develop small businesses. In response to the question, "How do you evaluate the raw material supply and processing capacity of your firm?" an edible oil processor in Nekemte town responded as follows:

Farmers sell niger seed during peak times. During lean times, it is difficult to get the raw material. I can't afford to buy large quantities and store in a warehouse to continuoushy process edible oil. Therefore, I buy a bit, process, sell the oil, and then use the money to buy the raw material again. It is just 
this cycle. (PI, male processor in Nekemte town)

The processor's response not only tells us about the subsistence nature of the production; it also indicates the financial problem limiting his capacity to buy more grains during peak times and store in his warehouse to continuously process niger seed oil for the market even during lean production times.

Interregional traders: This study also indicates that the maize buyers and collectors in Uke district town come either from the region or bordering regions, showing the significance of the center not only to the district but also to other surrounding districts and regions. Larger traders are mostly involved in the interregional trade, while small traders and intermediaries carry out interdistrict trade. The small traders or the representatives of the large traders collect the cereals and oilseeds from the farm gate and in turn sell to the large traders in the district towns. Uke district town is a center of business, particularly where most of the agricultural products from the northwest of the district and other bordering districts of Amhara $\left(11^{\circ} 30^{\prime} 00^{\prime \prime} \mathrm{N}\right.$ and $\left.38^{\circ} 30^{\prime} 00^{\prime \prime} \mathrm{E}\right)$ and Benishangul $\left(11^{\circ} 0^{\prime} 0^{\prime \prime} \mathrm{N}\right.$ and $\left.35^{\circ} 30^{\prime} 00^{\prime \prime} \mathrm{E}\right)$ regions converge. Therefore, this small town is the center for most agricultural production transactions. An interview with a collector and buyer in Uke district town underlines the role the center plays in the economic development of the locality:

\section{I collect maize from both farmers and other small collectors and sell to traders coming from even as far as Mekele town (in Tigray region). They come with their trucks and collect from the local collectors. (PI, male local collector in Uke FA)}

Uke district town is not only the center of domestic trade; it also serves as a source of production for external markets coming into the district. Domestically, farmers easily get their grains to the center after travelling short distances using mostly mule-drawn carts. Traders and collectors also come from Nekemte town on Tuesdays and Fridays, the two market days of Uke district town.
From outside Oromia region, buyers visit Uke market from Tigray and Amhara regions in the north and Benishangul-Gumz region in the west. Others also come from within the region, but out of the district and zone such as Harar from east Oromia region. These external buyers usually come on bigger market days (Tuesday). Before they come with their trucks, they contact the local larger collectors and traders to ensure they can get ample amounts of grains (mainly maize). The local traders then collect the maize from the farmers, store it in their warehouses, and inform the external traders that they can come and buy. Through this process Uke district town benefits from the external buyers generating more income for the district, as the external buyers use additional services in the center, such as including bars and restaurants. This also encourages diversification of activities in the locality following the market demands.

Why rural-urban linkages remained weak: The lack of a clearly defined policy framework to strengthen rural-urban economic linkages across Ethiopia contributes to the weak rural-urban linkages in the study area (Zewdu \& Malek, 2010). Apart from acknowledging the significance of the linkages in LED processes (MoWUD, 2009), the specific roles of urban centers and their relationships with their hinterlands are not articulated in the development policy of the country. Nekemte city administration and Guto Gidda district each have distinct development plans despite on-theground and inevitable linkages between the two. The current economic linkages between Nekemte town and its hinterlands could be improved if the local government were to implement the ruralurban integrated development plan. However, local officials have never consulted farmers and other value chain actors about how best to link a rural development plan to the urban development plan.

\section{Discussion of Findings}

\section{Rural-urban linkages in Guto Gidda district}

The mutual relationship between urban and rural areas is vital for LED. Nekemte town and Uke district town play instrumental roles in the LED process of the district by transforming the 
economies of both the urban and rural areas. They serve as markets and service centers for local agricultural producers. They also provide retail outlets and services for populations living in and around the cities. Uke district town in particular is very close to farmers who can easily sell their products without incurring additional transportation and other costs. Some farmers own businesses in this town that help them to generate income from nonfarm activities. In fact, the majority (approximately $75 \%$ ) of rural residents elsewhere in Oromia region move to their nearby towns (Dera and Iteya towns) in search of casual wage labor jobs (Gibson \& Gurmu, 2012). Uke district town also serves as a connection point for domestic (district) and external traders, generating more income for the district (Satterthwaite \& Tacoli, 2003). External buyers use the services the district town provides, including bars and restaurants, which adds to the local economy. This also encourages the diversification of activities in the locality following the local market demands.

Diversification of economic activities is not necessarily the result of economic growth. In theory, rural-urban linkages facilitate diversification, particularly in the rural areas. Under normal conditions, higher income in rural population is positively correlated with diversification, fulfilling the "virtuous circle" of rural-urban linkages and development (Tacoli, 2004). Results in Guto Gidda district, however, show that diversification is mostly a "survival strategy" (Figure 1) aiming at risk avoidance and used as a temporary remedy for poverty reduction rather than as a strategy for increasing income (Manjur, Amare, HaileMariam, \& Tekle, 2014). This diversification is not the result of capital and asset accumulation except in the case of large-scale farmers and traders, which may be attributed to their better market intelligence and access to capital. Rather, it is the result of agricultural push factors aimed at survival and/or risk management strategy (Assan, 2014; Fenton, 2013). These push factors include the shortage of farmland, low land productivity, and lack of capital, which all lead to food insecurity. These factors and others, such as increased costs of agricultural inputs, absence of modern irrigation schemes, and low dedication of DAs, are documented major constraints to agricultural productivity in the district (GGFEDO, 2013). This strategy, in turn, aims at reducing risk, overcoming seasonal fluctuations, and responding to shocks and stresses coming from within and without (such as erratic rainfall, poor pricing, poor social services, and poor roads), which are temporary remedies. However, this diversification clearly contributes to the production-consumption linkages between urban and rural areas.

The shortages and low productivity of farmland and unaffordability of agricultural inputs results in subsistence production among the farmers. This low productivity leads to low supply to the market, which weakens the forward and backward sectoral linkages between agriculture and non-agriculture sectors, and results in weak LED. The off-farm and nonfarm activities are unable to provide continuous income as they are casual jobs, and thus are a temporary remedy for food security. When it is time for cultivation, the farmers resort to their small-scale farm, which completes the "survival" strategy of rural-urban linkages.

\section{Spontaneous rural-urban linkages}

Unorganized rural-urban linkages may not well forge strong LED. There are ad hoc mutual interdependencies between the people living in urban and rural areas through production-consumption linkages that influence the livelihoods of the people and ultimately the LED in the study area. However, these linkages are unable to generate effective and strong resource cycles between rural and urban areas because of contextual factors such as lack of infrastructure, access to land, credit and policy guidance, and coordinated planning between the two (Adugna \& Hailemariam, 2011). These barriers negatively affect the sectoral forward and backward linkages between agriculture and industry, thus contributing to weak LED at present.

The economy of the district is at subsistence scale. The capacity of the two areas to provide each other with sufficient quantities of commodities is challenged. The absence of surplus production in rural areas contributes to the low development of agro-processing industries in Nekemte town. The rural population suffers the interwoven problems of poverty that include low productivity, low 
purchasing power, shortage of land, and limited access to credit. The majority of rural residents cannot afford to buy processed or semiprocessed urban products such as edible oil, sugar, and agricultural inputs (Zewdu \& Malek, 2010). This condition also applies to some of the urban poor, who have no informal or family relations with the rural households to access rural products and have insufficient monies to purchase from urban markets. The ability of farmers to maximize market access for their products is also challenged by poor infrastructure, such as lack of access to good market information (that is, how markets operate), as these reinforce local interactions. The absence of employment opportunities in the nonfarm sector in Nekemte town also contributed to the low level of income both in urban and rural areas.

In a nutshell, the weak linkages between Nekemte and its hinterlands negatively affected the development of the locality. Diversification in the study area is not only limited to off-farm and nonfarm activities. It is also diversification related to income, which includes activities that could be strategically allied to or are complementary to their primary source of income (Alemu, 2012). Most rural and urban households rely on the combination of farm and nonfarm activities to reduce risk and uncertainties of poverty. However, their agricultural production does not go beyond subsistence level, and thus its contribution to sustainable LED is negligible. The farmers, traders, and smallscale manufacturers engage in rural-urban linkages as a self-guided survival strategy. The lack of policy guidance and strategic direction means that poverty remains endemic and deeply embedded. This also results in the absence of a dialogue among the people of both areas on a commonly shared ruralurban development plan, leading to linkages that cannot generate a strong LED. The current sectoral LED project of Nekemte town acknowledges the importance of rural-urban linkages for sustainable urban development. It stresses the need to give particular attention to those economic sectors that foster and enhance rural-urban linkages, specifically prioritizing the development of microand small-scale enterprises. Unfortunately, there is no mention of representation from the rural areas in the project despite its aim of bringing different actors together to plan, implement, and manage initiatives to stimulate this urban-based LED.

\section{Conclusions and Recommendations}

This study revealed that the spatial and sectoral linkages between Nekemte and its hinterlands are challenged by factors related to infrastructure, production capacity, lack of guidance and coordinated planning, and low purchasing power of most of the residents. The absence of employment opportunities in the nonfarm sector in the town contributes to the low level of income in both the town and rural areas. The subsistence nature of production in the rural areas hampers the rural areas' capacity to meet the demands of the urban residents. Nekemte town, too, is unable to provide sufficient semiprocessed and processed products, and this has led to weak rural-urban linkages and a weak local economy. The national government lacks a sufficiently strong policy framework to enhance rural-urban linkages, and a sector-based LED approach persists. Further, the potential linkages between Nekemte and its hinterlands are challenged by a lack of reliable market information between the farmers and traders. As a result, ruralurban linkages in Guto Gidda district are prone to mistrust and multiple inefficiencies.

This study recommends development of innovative marketing relationships between the value chain actors, including farmers, traders, and smallscale manufacturers, to encourage the flow of reliable market information. This could strengthen urban-rural linkages, help bridge the existing divide, and promote mutually beneficial feedback loops to generate a stronger local economy. Levels of production can be increased by facilitating the access of farmers to affordable modern agricultural inputs, extension, and favorable rural microfinance. Microfinance services are necessary to assist farmers to buy agricultural inputs; otherwise they will not develop the capacity to meet market demand. In parallel, markets need to be strengthened in order to ensure that farmers can recoup their investments. A continuous, reliable, and sufficient supply of raw materials to urban residents is required to help to improve the processing capacity of the urban areas to generate strong local economies.

It is important to develop an integrated LED 
program in collaboration with stakeholders from both urban and rural areas, starting with design and piloting and through to implementation and evaluation. This will help to improve value chain governance mechanisms and strengthen transparency, thus enhancing trust. Networks of individuals who strengthen social interactions and healthy personal relationships among the people through indigenous institutions could improve the production capacity of farmers and facilitate rural-urban linkages. Establishing better institutional arrangements, such as a well developed marketing structure, could also strengthen the linkages. Improving the provision of physical infrastructures such as rural feeder roads and better and more reliable power supplies would facilitate the flow of resources between urban and rural areas and increase the processing capacity of edible oil processors.

\section{Acknowledgement}

I thank my supervisors, Associate Professor Robyn Eversole (director of the Institute for Regional Development) and Laurie Bonney (associate professor in value chain innovation research, Tasmanian Institute of Agriculture), who continuously read and commented on this paper.

\section{References}

Abate, T., Shiferaw, B., Menkir, A., Wegary, D., Kebede, Y., Tesfaye, K., Kassie, M., Bogale, G., Tadesse, B., \& Keno, T. (2015). Factors that transformed maize productivity in Ethiopia. Food Security, 7(5), 965-981. http://dx.doi.org/10.1007/s12571-015-0488-z

Adugna, A., \& Hailemariam, A. (2011). Rural-urban linkages in Ethiopia: Insuring rural livelihoods and development of urban centers. In C. Teller \& A. Hailemariam (Eds.), The Demographic Transition and Development in Africa: The Unique Case of Ethiopia (pp. 167-186). Netherlands: Springer

Akkoyunlu, Ş. (2013). The potential of rural-urban linkages for sustainable development and trade (NCCR Trade Working Paper No. 2013/37). Bern, Switzerland: Swiss National Science Foundation.

Alemu, Z. G. (2012, August). Livelihood strategies in rural South Africa: Implications for poverty reduction. Paper presented at the International Association of Agricultural Economists (IAAE), Triennial Conference, Foz do Iguacu, Brazil.
http://econpapers.repec.org/RePEc:ags:iaae12:125 $\underline{411}$

Allaro, H. B. (2011). Export performance of oilseeds and ITS determinants in Ethiopia. American Journal of Economics, 1(1), 1-14. http://dx.doi.org/10.5923/ j.economics.20110101.01

Assan, J. K. (2014). Livelihood diversification and sustainability of rural non-farm enterprises in Ghana. Journal of Management and Sustainability, 4(4), 1-14. http://dx.doi.org/10.5539/ims.v4n4p1

Curry, L. A., Nembhard, I. M., \& Bradley, E. H. (2009). Qualitative and mixed methods provide unique contributions to outcomes research. Circulation, 119(10), 1442-1452. http://dx.doi.org/10.1161/ CIRCULATIONAHA.107.742775

Dalipagic, I., \& Elepu, G. (2014). Agricultural value chain analysis in northerm Uganda: Maire, rice, groundnuts, sunflower and sesame. New York: Action Against Hunger (ACF-International). Retrieved from http://www.actionagainsthunger.org/publication/ 2014/03/agricultural-value-chain-analysis-northernuganda-maize-rice-groundnuts

Dorosh, P. A., Alemu, G., De Brauw, A., Malek, M., Mueller, V., Schmidt, E., Tafere, K., \& Thurlow, J. (2011). The rural-urban transformation in Ethiopia (ESSP II - EDRI Report). Addis Ababa, Ethiopia: Ethiopian Strategy Support Program II (ESSP II), International Food Policy Research Institute. Retrieved from https://www.ifpri.org/publication/ rural-urban-transformation-ethiopia-0

Dorosh, P., \& Rashid, S. (Eds.). (2013). Food and agriculture in Ethiopia: Progress and policy challenges. Philadelphia: University of Pennsylvania Press. http://dx.doi.org/10.9783/9780812208610

Dorosh, P., \& Thurlow, J. (2013). Agriculture and small towns in Africa. Agricultural Economics, 44(4-5), 449459. http://dx.doi.org/10.1111/agec.12027

Dorward, A., Anderson, S., Bernal, Y. N., Vera, E. S., Rushton, J., Pattison, J., \& Paz, R. (2009). Hanging in, stepping up and stepping out: Livelihood aspirations and strategies of the poor. Development in Practice, 19(2), 240-247. http://dx.doi.org/10.1080/09614520802689535

Engelmann, R., \& Isiaho, R. (2005). An inventory of BDS Market Assessment methods for programs targeting microenterprises. Retrieved from the SEEP Network website: http://www.seepnetwork.org/aninventory-of-bds-market-assessment-methods-forprograms-targeting-microenterprises-resources206.php 
Federal Democratic Republic of Ethiopia [FDRE]. (2010). Growth and transformation plan. Addis Ababa: National Planning Commission.

FDRE. (2015). The second growth and transformation plan (GTP II) (2015/16-2019/20) (Draft) Addis Ababa: National Planning Commission.

FDRE, Central Statistical Agency [CSA]. (2013). Population projection of Ethiopia for all regions at wereda level from 2014 - 2017. Addis Ababa: Author. Retrieved from http://www.csa.gov.et/

FDRE \& U.N. Development Programme [UNDP]. (2012). Support to Local Economic Development (LED) Programme, 2nd Generation Programme, 2012-2015.

Retrieved from the UNDP website: http://www.undp.org/content/dam/undp/ documents/projects/ETH/LED ProgDoc Final 08Nov 2012.pdf

Fenton, I. (2013). Rural-urban linkages in development: Is strengthening agriculture the best way forward? A case study from Guatemala. Agriculture for Development, 2013(18), 37-40. http://www.taa.org.uk/

Fitsum, M. D. (2013). The role of small towns in diversiffing the livelihood of rural communities: The case of Samre Town Sabarti Samre District, Tigray, Ethiopia (Master's thesis). Mekelle University, Mek'ele, Ethiopia. Retrieved from https://opendocs.ids.ac.uk/ opendocs/handle/123456789/4479

Fritsche, U. R., Eppler, U., Iriarte, L., Laaks, S., Wunder, S., Kaphengst, T., Wolff, F., Heyen, D., \& Lutzenberger, A. (2015). Resource-efficient land use Towards a global sustainable land use standard (Report No. [UBA-FB] 002165/E). Dessau-Rosslau, Germany: Umweltbundesamt. Retrieved from http://www.umweltbundesamt.de/publikationen/ resource-efficient-land-use-towards-a-global

Gebre-Selassie, A., \& Bekele, T. (2012). A review of Ethiopian agriculture: Roles, policy and small-scale farming systems. In C. Bell \& J. Prammer (Researchers), C. Eder, D. Kyd-Rebenburg, \& J. Prammer (Eds.), Global growing casebook: Insights into African agriculture (pp. 36-65). Retrieved from http://global-growing.org/sites/default/files/ GGC Ethiopia.pdf

Geleta, D., Birhanu, Z., Kaufman, M., \& Temesgen, B. (2015). Gender norms and family planning decision-making among married men and women, rural Ethiopia: A qualitative study. Science Journal of
Public Health, 3(2), 242-250.

http://dx.doi.org/10.11648/i.siph.20150302.23

Gete, Z., Trutmann, P., \& Aster, D. (Eds.). (2007). Fostering new development pathways: Harnessing ruralurban linkages (RUL) to reduce poverty and improve environment in the highlands of Ethiopia (Proceedings of a planning workshop on Thematic Research Area of the Global Mountain Program (GMP), Addis Ababa, Ethiopia.) http://hdl.handle.net/10568/63521

Gibson, M. A., \& Gurmu, E. (2012). Rural to urban migration is an unforeseen impact of development intervention in Ethiopia. PLOS One, 7(11), e48708. http://dx.doi.org/10.1371/journal.pone.0048708

Guto Gidda Finance and Economic Development Office [GGFEDO]. (2013). Physical and Socioeconomic profile of Guto Gidda District, Nekemte, Ethiopia

Jalata, G. G. (2015, July). An African developmental state: Ethiopia's emergent experience. Paper presented at the Regional Conference on Building Democratic Developmental States for Economic Transformation in Southern Africa, Pretoria, South Africa. Retrieved from http://developmentalstatesconference.com

Jolejole-Foreman, M. C., Baylis, K., \& Lipper, L. (2012, August). Land degradation's implications on agricultural value of production in Ethiopia: A look inside the bowl. Paper presented at the International Association of Agricultural Economists (IAAE) Triennial Conference, Foz do Iguacu, Brazil. Retrieved from ResearchGate website: http://www.researchgate. net/publication/254387428

Khor, M. (2006). Globalisation, liberalisation, and protectionism: The global framework affecting rural producers in developing countries. Penang, Malaysia: Third World Network. Retrieved from http://www.twn.my/ title2/par/MK global agric paper for ifad 23 march 2006.doc

Kvale, S. (1996). InterV iews: An introduction to qualitative research interviewing. Thousand Oaks, California: SAGE.

Magel, H. (2004). Marrakech Declaration: Urban-rural interrelationship for sustainable environment (FIG Publication No. 33). Frederiksberg, Denmark: International Federation of Surveyors. Retrieved from http://www.fig.net/pub/figpub/pub33/ figpub33.pdf 
Makosa, D. (2015). Constraints and opportunities to upgrading Uganda's rice markets: A value chain approach. Journal of Development and Agricultural Economics, 7(12), 386-399. http://dx.doi.org/10.5897/JDAE2015.0643

Manjur, K., Amare, H., HaileMariam, G., \& Tekle, L. (2014). Livelihood diversification strategies among men and women rural households: Evidence from two watersheds of northern Ethiopia. Journal of Agricultural Economics and Development, 3(2), 17-25. http://www.academeresearchjournals.org/journal/ jaed/

McGranahan, G., \& Satterthwaite, D. (2014). Urbanisation concepts and trends (IIED Working Paper). London: International Institute for Environment and Development (IIED). Retrieved from http://www.iied.org/pubs

Ministry of Finance and Economic Development [MoFED]. (2005). Ethiopia: Building on progress: $A$ Plan for Accelerated and Sustained Development to End Poverty (PASDEP) (2005/06-2009/10). Addis Ababa.

MoFED. (2007). Ethiopia: Building on progress: A Plan for Accelerated and Sustained Development to End Poverty (PASDEP). Annual progress report 2006/07. Addis Ababa: Author. Retrieved from https://cooper acionetiopia.files.wordpress.com/2011/01/pasdepannual-progress-report-2006-2007.pdf

Ministry of Works and Urban Development [MoWUD]. (2009). Rural-urban linkage manual. Federal urban planning coordinating bureau. Addis Ababa.

Mushir, A., \& Meaza, H. M. (2013). Rural-urban linkages, models and approaches: An overview. International Journal of Advanced and Innovative Research, 2(8), 272274. http://www.advanceresearchlibrary.com/ ijairp15.aspx

NCD. (2012). Physical characteristics of Nekemte town administration. Nekemte: Nekemte City Administration.

Nemes, G. (2005). Integrated rural development - The concept and its operation (IEHAS Discussion Paper No. 506). Institute of Economics, Hungarian Academy of Sciences. Retrieved from the EconPapers website: http://EconPapers.repec.org/RePEc:has:discpr:05 $\underline{06}$

The Nationl Regional Government of Oromia [NRGO]. (2014). Statistical abstract 13th edition. Finfinne.

Nuru, A. S. (2015, March). Investing on capabilities: High economic growth, high hope for economic transformation: The Ethiopian Experience. Paper presented at the 2015
International Conference on the Emergence of Africa, Abidjan, Côte d'Ivoire. Retrieved from http://www.africa-emergence.com/fichier/doc/ Investing on capabilities.pdf

ORS. (2014). Regional statistics. East Wollega Zone Ana's socio economic profile. Finfinne: The National Regional Government of Oromia.

Regassa, S., Givey, C., \& Castillo, G. E. (2010). The rain doesn't come on time anymore: Poverty, vulnerability, and climate variability in Ethiopia (Oxfam International Research Report). Oxfam International. Retrieved from https://www.oxfam.org/en/research/raindoesnt-come-time-anymore

Sani, M. M. J., \& Far, A. H. (2015). Effects of small town's centralization on spatial organization of rural settlement (Case Study: Hesar Sorkh \& Hesar Golestan - Torqabeh \& Shandiz cities). Journal of Applied Geology and Geophysics 3(1), 31-39. http://www.iosrjournals.org

Satterthwaite, D., \& Tacoli, C. (2003). The urban part of rural development: The role of small and intermediate urban centres in rural and regional development and poverty reduction (Working Paper No. 9). London: IIED.

Saunders, M., Lewis, P., \& Thornhill, A. (2009). Research methods for business students (5th edition). Harlow, Essex, UK: Pearson Education.

Sietchiping, R., Kago, J., Zhang, X. Q., Augustinus, C., \& Tuts, R. (2014). Role of urban-rural linkages in promoting sustainable urbanization. Environment and Urbanization Asia, 5(2), 219-234. http://dx.doi.org/10.1177/0975425315577170

Siechiping, R., Kago, J., Zhang, X.-Q., Augustinus, C., \& Tuts, R. (2015, March). Urban-rural linkages and the role of land tenure. Paper presented at the 2015 Annual World Bank Conference on Land and Poverty, Washington, D.C.

Steinberg, F. (2014, October). Rural-urban linkages: An urban perspective (Working Paper Series No. 128). Paper presented at the Territorial Cohesion for Development Program, Rimisp, Santiago, Chile. Retrieved from http://rimisp.org/wp-content/ files $\mathrm{mf} / 1422298948 \mathrm{R}$ ULinkages Urbanperspec tive_Final_edited.pdf

Syume, M., \& Chandravanshi, B. S. (2015). Nutrient composition of niger seed (Guizotia abyssinica (L. f.) Cass.) cultivated in different parts of Ethiopia. Bulletin of the Chemical Society of Ethiopia, 29(3), 341-355. http://dx.doi.org/10.4314/bcse.v29i3.2 
Tacoli, C. (2004, June). Rural-urban linkages and pro-poor agricultural growth: An overview. Paper presented at the OECD DAC POVNET Agriculture and Pro-Poor Growth Task Team, Helsinki. Retrieved from https://www.oecd.org/dac/povertyreduction/3656 2896.pdf

Tacoli, C., McGranahan, G., \& Satterthwaite, D. (2015). Urbanisation, rural-urban migration and urban poverty (IIED Working Paper). London: IIED. Retrieved from http://pubs.iied.org/pdfs/10725IIED.pdf

Tegegne, G. E. (2001). Rural-urban linkages under different farming systems: The case of coffee and non-coffee growing regions in Ethiopia (Social Science Research Report Series No. 21). Addis Ababa: Organization for Social Science Research in Eastern and Southern Africa (OSSREA). http://dspace.africaportal.org/ jspui/bitstream/123456789/32009/1/SSRR21 complete1.pdf

Tenaw, S., \& Islam, K. M. Z. (2009). Rural financial services and effects of microfinance on agricultural productivity and on poverty (Discussion Papers No. 37). Helsinki: University of Helsinki, Department of Economics and Management. Retrieved from http://www.helsinki.fi/taloustiede/Abs/DP37.pdf

Teshome, A. (2006). Agriculture, growth and poverty reduction in Ethiopia: Policy processes around the new PRSP (PASDEP). Paper presented at the Future Agricultures Consortium Workshop, Institute of Development Studies, University of Sussex, Brighton, UK. Retrieved from http://www.futureagricultures.org/74-publications/policy-briefs/185agriculture-growth-and-poverty-reduction-inethiopia-policy-processes-around-the-new-prsppasdep
Trienekens, J. H. (2011). Agricultural value chains in developing countries: A framework for analysis. International Food and Agribusiness Management Review, 14(2), 51-82.

United Nations [UN]. (2011). Population distribution, urbanization, internal migration and development: $A n$ international perspective. New York: Author. Retrieved from http://www.un.org/esa/population/ publications/PopDistribUrbanization/Population DistributionUrbanization.pdf

Von Braun, J. (2007, June). Rural-urban linkages for growth, employment, and poverty reduction. Keynote address at the Fifth International Conference on "Ethiopian Economy," Addis Ababa. Retrieved from https://www.ifpri.org/publication/rural-urbanlinkages-growth-employment-and-povertyreduction-0

Yin, R. K. (2008). Case study research: Design and methods (4th Edition). Thousand Oaks, California: SAGE.

Zewdu, G. A., \& Malek, M. (2010). Implications of land policies for rural-urban linkages and rural transformation in Ethiopia (Ethiopia Strategy Support Program II Working Paper No. 15). Addis Ababa: International Food Policy Research Institute and Ethiopian Development Research Institute. http://citeseerx.ist.psu.edu/viewdoc/download? $\underline{\text { doi }=10.11 .227 .1222 \& r e p=D r e p 1 \% 26 t y p e}=$ pdf 